$\frac{\frac{\text { NATIONAL }}{\text { ACADEM Y }}}{\frac{\text { OF・SOCIAL }}{\text { INSURANCE }}}$

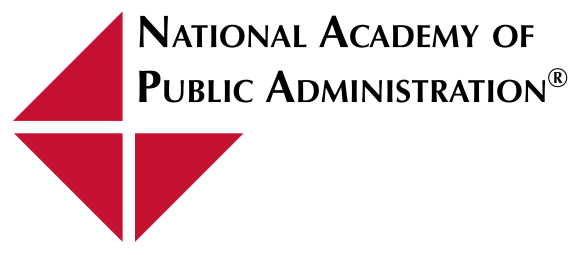

\title{
The Regulation of Private Health Insurance
}

JANUARY 2009

by Timothy Stoltzfus Jost

Washington and Lee University School of Law 


\title{
THE REGULATION OF PRIVATE HEALTH INSURANCE
}

\author{
Timothy Stoltzfus Jost
}

\section{Introduction}

This paper examines the current role of health insurance regulation and the role that it could play in a reformed health care system. It begins by exploring the nature of health insurance and alternative approaches to its regulation. It next considers the current status of first state and then federal health insurance regulation, both describing the development of health insurance regulation and examining arguments in support of and in opposition to regulatory interventions. Finally, it considers the kind of insurance regulation that will be needed in a reformed health care system, as well as the question of whether authority for insurance regulation should be placed at the federal or state level.

\section{The Health Insurance Relationship}

At its core, the insurance relationship is based on a contract under which the insured pays money to an insurance company at one point of time with the understanding that if certain losses described in the contract eventuate at a later point in time, the insurer will cover the loss. The insurer pools risk, collecting premiums from many insureds, only a few of whom will recover their full premium, at least in the short run (and many insureds have only a short-term relationship with health insurers.) The insurer, however, is at risk of paying out large sums of money for the benefit of a few of its insureds in the short run, and for the benefit of many more in the long run if the relationship persists.

This relationship is inherently problematic. First, its viability depends on the financial capacity of the insurer to respond to the claims of its insureds, the total of which can potentially exceed the sum total of premiums received. Second, the insured depends on the insurer's good faith and efficient business practices for the prompt and fair payment of claims. In the short run at least, it may be in the financial interest of the insurer to delay payment of claims and to dispute claims that are in any way questionable, or even to refuse to pay legitimate claims. Third, an insurance contract is typically a long and complex instrument, drafted by the insurer. Few terms, if any, are negotiated. It is what is known in the law as an adhesion contract. ${ }^{1}$ The insured is largely dependent on the insurer for assuring that this contract meets the reasonable expectations of the insured as to the coverage that is being purchased and that it does not contain terms that can be used unfairly to deny coverage when risks eventuate. Finally, the insured is largely dependent on the marketing practices of the insurer to understand the nature of the insurance product that is being purchased and to avoid unreasonable expectations as to the extent of coverage.

\footnotetext{
${ }^{1}$ See, e.g. Hospital Authority of Houston County v. Bohannon, 611 S.E.2d 663 (Ga.App. 2005).
} 
The insurance transaction is further complicated by the problems of adverse selection and moral hazard. ${ }^{2}$ Adverse selection in its classic form is a function of information asymmetries between the insurance applicant and insurer. The applicant generally knows more about the extent and nature of the risk the applicant faces than does the insurer, and is more likely to secure insurance if that risk is perceived to be greater than normal. The insurer, therefore, has to worry about being taken advantage of by applicants who expect a risk to eventuate. Adverse selection, moreover, not only makes it more likely that persons at high risk will purchase insurance, but also that they will purchase more complete coverage than those who perceive themselves to be at low risk. Thus adverse selection affects not only the market as a whole, but also disadvantages specific insurers or policies that offer more comprehensive coverage. Insurers respond to the threat of adverse selection by carefully assessing the risks they insure, denying coverage to high risk insureds in some instances or charging them higher rates in others, and by attempting to shed themselves of bad risks that they fail to avoid in the first place (practices known as favorable selection or "cherry picking”). Insurers can also refuse to insure preexisting risks, impose waiting periods before certain risks are covered, or scrutinize applications carefully once a claim is made for potential misrepresentations (a practice known as “post-claims underwriting”). ${ }^{3}$

Moral hazard refers to the fact that once a risk is insured it is more likely to be incurred. Under some circumstances insurers may be at risk of "ex ante” moral hazard. An insured driver may drive less carefully, a person with health insurance may smoke more or exercise less. ${ }^{4}$ More important is the problem of "ex post" moral hazard: once insured a person is more likely to incur a loss, particularly if the insured has some ability to cause the insured loss and the possibility of recovering a payment from the insurer that exceeds the true extent of the loss. The classic example of moral hazard is the insured ship owner scuttling a ship to collect on the insurance policy.

${ }^{2}$ See Kenneth S. Abraham, Distributing Risk: Insurance, Legal Theory, and Public Policy (New Haven: Yale, 1986), 14-16.

${ }^{3}$ This practice was recently disapproved of in Hailey v. California Physician's Services, 2007 WL 4472790 (Cal.App. 4 Dist., 2007), which held that an insurer cannot rescind an insured's contract for misrepresentation in an application after a claim is filed unless the misrepresentation was willful and the insurer had made reasonable efforts to determine the application's accuracy at the time of application.

${ }^{4}$ This is probably more of a theoretical problem than a real problem. I know of no evidence that uninsured drivers drive more carefully than insured drivers, or that persons without health insurance exercise more or smoke less than insured persons. The Rand Health Insurance Experiment failed to find any evidence of ex ante moral hazard with respect to health insurance, although it did find significant evidence of ex-post moral hazard. See Joseph Newhouse, Free for All? Lessons from the Rand Health Insurance Experiment (Cambridge: Harvard University Press, 1993), 200-01, 208. 
The health insurance transaction poses its own peculiar problems beyond those experienced with other kinds of insurance. First, it is very difficult, if not impossible, to fully specify in advance the coverage of a health insurance contract. There are simply too many products and services potentially covered by a health insurance contract to completely describe what is covered and what is not. Typically, policies have used terms like "medically necessary services," but under such policy language everything depends on who decides what is necessary and what procedures are followed in making and reviewing that determination. Second, because of the complexity of health and health care, it is often very difficult for the insured to understand in advance the extent of coverage needed. In particular, insurance applicants are unlikely to fully comprehend the nature and extent of the risks against which they are insured, and are likely to use heuristic devices to choose the extent of coverage to purchase. ${ }^{5}$ An applicant may, for example, purchase insurance for a particular kind of cancer from which the purchaser's aunt has recently died, but forego coverage for another condition that is much more likely to occur.

The market dynamics of the health insurance transaction are also unusual. In most markets, sellers are particularly attentive to their high use customers. Businesses have every reason to cater to those who demand a high volume of their products or services to keep their loyalty and to secure return business. Precisely the opposite is true in health insurance markets. Insurers lose money on individuals or groups who need extensive and expensive health care services and thus face an incentive to underserve these insureds, to encourage them to disenroll, or even to cancel coverage if possible. This is particularly true if the insurer is limited in its ability to charge higher premiums for high-risk insureds by state law, but even an insurer who can charge risk-based premiums may underestimate the true cost of a policy and attempt later to shed itself of its obligations. Of course, an insurer cannot ignore the reputational effects it may suffer if it consistently underserves its insureds, but an insurer that provides excellent service to its low-cost insureds (providing hassle-free coverage for primary and preventive care for example), or even for its otherwise healthy insureds who periodically experience higher-cost episodes, like sports injuries or normal maternity care, may well be able to get away with providing inferior coverage or service for rare but very high cost events, like organ transplants.

Serious agency problems also attend health insurance markets. First, most American receive health care coverage either through their place of employment or through a government program. Ultimately all health insurance is paid for by individuals, if not directly through premiums then as taxpayers or as employees who receive less in wages and in other benefits because of the cost of health insurance. ${ }^{6}$ Persons who are insured through a government

${ }^{5}$ See Russell Korobkin, The Efficiency of Managed Care Patient Protection Laws: Incomplete Contracts, Bounded Rationality, and Market Failure, 85 Cornell L. Rev. 1 (1999); Amy Monahan, Federalism, Federal Regulation, or Free Market? An Examination of Mandated Benefit Reform, 2007 University of Illinois Law Review 1361 (2007).

${ }^{6}$ See Robert Evans,, Financing Health Care: Options, Consequences, and Objectives” in Gregory P. Marchildon, Tom McIntosh, and Pierre-Gerlier Forest eds., The Fiscal Sustainability of Health Care in Canada (The Romanow Papers: Vol. 1) (Toronto: University of Toronto Press, 2004), 139 at 143. 
program or through their place of employment, however, are unlikely to be immediately aware of the cost of their insurance coverage, and depending on how costs are distributed among employees or taxpayers, may have little responsibility for that cost. ${ }^{7}$ Tax subsidization of employment-based insurance further removes insureds from the cost of insurance. The risk of moral hazard may, therefore, be enhanced in employment-based or public insurance.

The fact that most private health insurance in the United States is purchased by employers (or provided directly by self-insured employers) affords significant advantages. ${ }^{8}$ Insured employees benefit from the expertise of employers in purchasing, as well as from economies of scale. Agent commissions, for example, account for a significant proportion of the cost of nongroup policies, but are much less of a factor in employment-based insurance. Insurers also face much less of a risk of adverse selection from employment-based policies (at least those that insure large employers) because the primary insureds are healthy enough to work, employment is usually sought because of factors other than the desire for insurance for an anticipated risk, and the size of employment-based pools significantly decreases the risk to which an insurer is exposed from any one individual. Insurers can thus afford to give employers a better rate than they would normally give individuals, where the risk of adverse selection is much higher.

On the other hand, employers that provide health benefits are purchasing (or selfinsuring) a policy to cover all of their insured employees, and may not secure the coverage that is most valuable to any particular employee. Also, employers must be concerned about the cost of insuring their employees, and this concern may overshadow other concerns such as difficulties their employees may encounter with claims processing or generosity of coverage, especially for uncommon conditions. Insurance coverage is also less stable because it is employment based. While individuals often have long term relationships with their auto, home, or life insurers, they are likely to change health insurers whenever they change jobs, and employers often change insurers from year to year as they look for the best bargains in the market. Finally, insureds play little role in negotiating employment-based insurance contracts and may not ever see the insurance contract itself, much less understand its terms.

When insureds need health care services, they encounter another agency problem. Although individual insureds usually decide whether or not to seek health care products and services, once they decide to do so, the scope of the products and services they receive is often

${ }^{7}$ See, considering the distributional impact of employment-related health insurance, Mark Pauly, The Tax Subsidy to Employment-Based Health Insurance and the Distribution of Well-Being, 69 Law and Contemporary Problems 83 (2006).

${ }^{8}$ See Sherry Glied, “The Employer-Based Health Insurance System: Mistake or Cornerstone?” in D. Mechanic, L. Rogut, \& D. Colby, eds., Policy Challenges in Modern Health Care (New Brunswick, NJ: Rutgers University Press 2005) at 37; David A. Hyman \& Mark A. Hall, Two Cheers for Employment-Based Health Insurance, 2 Yale Journal of Health Policy, Law \& Ethics, 23 (2001). 
out of their hands. ${ }^{9}$ Physicians and other health care professionals and providers largely determine what is ordered and provided. ${ }^{10}$ Patients often do not fully understand what particular services they need, much less how much those services cost. Rather, professionals and providers determine what services are provided (with some input from the patient) and often these same professionals and providers are paid for those same services. The risk of moral hazard is, therefore, significantly enhanced in health insurance transactions. Insurers and managed care organizations must address this moral hazard problem, and often provide the only real oversight of health care utilization and cost.

Finally, health insurance is unusual because health care is perceived to be different from other products and services, and health risks as different from other risks. In most developed countries, health care risks are publicly insured even though other personal risks (such as home fire or auto collision damage) are not. In the United States public insurance programs cover health risks for large populations, and support for a right of access to health care for all is widespread. ${ }^{11}$ At the individual level, health care transactions are often fraught with fear and anxiety. Life and limb can actually be at risk. Objective economic judgments are often difficult under these circumstances. Indeed, individuals may demand lower levels of cost-sharing than they might be comfortable with for other forms of insurance to avoid having to make economic trade-offs under stressful circumstances.

\section{The Governance of Health Insurance}

Given these characteristics of insurance in general and of health insurance in particular, how should insurance be governed? A number of possibilities are conceivable.

First, health insurance could be left completely unregulated, governed only by markets. The insurer and insured would negotiate the terms and price of coverage. Presumably the insurer would insist on full disclosure of known risks, charging a premium proportionate to the risk and imposing limitations of coverage necessary to protect itself against adverse selection and moral hazard. If the insurer was subsequently unwilling or unable to cover claims, it would suffer reputational injury and thus have a harder time finding customers in the future, but would experience no other consequences.

This approach, of course, does little to help the individual insured whose claim is denied

${ }^{9}$ This was a finding of the Rand Health Insurance Experiment, see Newhouse, supra note 4, at $42,45,82,98-99$.

${ }^{10}$ See Mark A. Hall \& Carl E. Schneider, Patients as Consumers: Courts, Contracts, and the New Medical Marketplace, 106 Michigan Law Review 643 (2008).

${ }^{11}$ Polls show that 75 to 80 percent of Americans believe that access to health care should be a right. See Kaiser Public Opinion Spotlight, http://www.kff.org/spotlight/uninsured/6.cfm. 
unfairly or in breach of the insurance agreement. At the very least, therefore, the market needs to be supplemented by judicial oversight--the possibility of lawsuits for breach of contract. Breach of contract lawsuits are common in insurance law. Insurers draft insurance contracts which would be expected to give them an advantage in contract litigation. Recognizing the imbalance of bargaining power in these transactions, however, the courts have come to the aid of the insured through the common law doctrine of contra preferentum, construing the contract against the insurer where it is ambiguous, and the doctrine of protecting the reasonable expectations of insureds. ${ }^{12}$ Some states have also permitted exemplary damages in bad faith breach of contract actions against insurers who have blatantly violated their contractual obligations. $^{13}$

Common law rights of insureds can also be supplemented by statutory rights enforceable through private litigation. ${ }^{14}$ These can take the form of general consumer protection statutes or can address particular insurance abuses, such as unfair claims settlement practices statutes. ${ }^{15}$ Such statutes can set basic standards for insurer obligations. They can make it more likely that insurance contracts offer the terms insureds are likely to expect or that insurers treat insureds fairly. They could also encourage insureds to protect their rights through litigation by offering statutory penalties or attorneys fees for prevailing insureds. ${ }^{16}$

Private litigation has significant limitations, however. ${ }^{17}$ First, it is very costly, timeconsuming, and generally inefficient. Unless a great deal of money is involved, it rarely pays for an insured to hire a lawyer and sue an insurer for a claim denial. Given the time it takes for a case to be resolved, moreover, litigation rarely meets the insured's immediate need for a service

12 See Abraham, supra note 2, at 101-132,

${ }^{13}$ See Tom Baker, Constructing the Insurance Relationship: Sales Stories, Claims Stories, and Insurance Contract Damages, 72 Tex. L. Rev. 1395 (1994).

${ }^{14}$ One example of this is the managed care liability statutes adopted in a number of states in the late 1990s. Mark A. Hall \& Gail Agrawal, The Impact of State Managed Care Liability Statutes, 22(5) Health Affairs 138 (2003).

15 See Steven Plitt \& Christine L. Kriegsfeld, The Punitive Damages Lottery Chase is Over: Is There a Regulatory Alternative to the Tort of Common Law Bad Faith and Does it Provide and Adequate Deterrent?, 37 Ariz. St. L.J. 1221 (2005).

${ }^{16}$ See, e.g. Vernon’s Ann. Mo. Stat. § 375.420; Fla. Stat. Ann. § 624.155.

${ }^{17}$ See Mark A. Hall, et al., Judicial Protection of Managed Care Consumers: An Empirical Study of Insurance Coverage Disputes, 26 Seton Hall L. Rev. 1055 (1996). The authors found only 203 reported decisions involving insurer medical appropriateness decisions from a thirty-four year period. The median amount involved was between $\$ 10,000$ and $\$ 50,000$ and the mean case took 2.5 years to resolve, although one quarter took four years or more. Plaintiffs won a slight majority of the cases. 
or for payment for a service. Because insurers usually draft contracts, which the insured often never even sees before a claim is made, insureds usually face an uphill battle. Moreover, insurers are "repeat players" in litigation, while insureds are not, and are usually in a superior position to understand and control the litigation process. For all of these reasons, insurers have good reason to discount the likelihood of losing, or even facing, litigation, and thus relying on litigation is unlikely to result in optimal protection of insureds.

The high costs and inefficiencies of litigation can be avoided through alternative dispute resolution mechanisms. Both the state and federal governments currently require health insurers to offer internal review mechanisms, which provide a quick and inexpensive approach to clearing up mistaken or ill-considered claim denials. ${ }^{18}$ Virtually all of the states also now provide for external review of managed care claim denials. ${ }^{19}$ External reviews, which are often binding, do not necessarily require insureds to hire lawyers and usually must be resolved within reasonably tight time frames. They provide an efficient approach to ensuring the insurers live up to their commitments.

Claims review is in some instances handled by private entities. Some managed care contracts expressly require arbitration of claims disputes, while some state statutes provide for the use of private contractors for external review. ${ }^{20}$ Fairness concerns arise when the insurer is permitted to choose the contract interpreter and enforcer, but unbiased private review entities may assist in providing efficient dispute resolution.

Private entities can also through accreditation provide a form of nongovernmental standardization and regulation of insurers. The National Council for Quality Assurance (NCQA), for example, accredits managed care organizations, providing standards with which accredited organizations agree to comply and offering insurance purchasers a means of identifying managed care organizations that accept these standards, and even, through the application of the HEDIS measures, a means of comparing the performance of accredited organizations.

Private dispute resolution and accreditation, and even litigation, are unlikely, however, to deal successfully with insurers guilty of out-and-out fraud. This is a serious problem, particularly during times when insurance premiums are increasing rapidly. A GAO report

${ }^{18}$ The federal regulations, governing ERISA plans, are found at 20 C.F.R. § 2560.503-1.

${ }^{19}$ See, reviewing the operation of these systems, Carole Roan Gresenz and David M. Studdert, External Review of Coverage Denials by Managed Care Organizations in California, 2(3) Journal Empirical Legal Studies 449 (2005); Leatrice Berman-Sandler, Independent Medical Review: Expanding Legal Remedies to Achieve Managed Care Accountability, 13 Annals of Health Law 233 (2004).

${ }^{20}$ See Nan D. Hunter, Managed Process, Due Care: Structures of Accountability in Health Care, 6 Yale Journal of Health Policy, Law \& Ethics 93 (2006). 
covering the years 2000-2002 found 144 entities that had sold bogus insurance in every state to 15,000 employers covering 200,000 insureds, leaving \$252 million in uncovered claims, only twenty-one percent of which had been recovered at the time of the survey. ${ }^{21}$ Insurance scams during the 1988-91 period left 400,000 people with more than \$123 million in unpaid bills. ${ }^{22}$ Ensuring the financial responsibility of insurers and preventing or sanctioning marketing and claims processing fraud are, at least, the responsibility of government regulation.

Regulation, however, can take different forms. Some administrative regimes, for example, operate through ex-post case-by-case adjudication and enforcement. The administrator simply waits until a statute is violated and then takes enforcement action, either through administrative adjudication or through litigation. Beyond this, administrators can promulgate regulations that expand and elaborate on a statutory scheme. In some instances issuing regulations requires explicit authorization, in other instances it is assumed to be within the general power of the regulator. Some regulators also offer advisory opinions or rulings, interpreting general regulations in the context of specific circumstances.

Finally, a regulator can become actively involved ex ante in supervising regulated entities, ensuring compliance with solvency and reserve requirements as a condition of granting licensure; reviewing pre-filed insurance policies and rates before use; periodically examining the regulated entity and auditing its books; or requiring regular reports. This form of oversight can be very prescriptive and intrusive and involve the regulator deeply in the operation of the regulated entity. With respect to some types of activity such as ensuring solvency, however, it might prove the most useful form of regulation. The text that follows examines the forms of insurance regulation that have in fact emerged in the United States, first at the state and then at the federal level.

\section{State Health Insurance Regulation}

\section{A. Early Regulatory Efforts}

Health insurance in the United States is a recent phenomenon, less than eighty years old. Prior to the 1930s, employers, unions, and religious and fraternal groups occasionally offered health care or benefits to their members, but modern health insurance did not exist. Health insurance in its contemporary form can be traced to the hospital prepayment plan offered by Baylor Hospital to the white public school teachers in Dallas, Texas in $1932 .{ }^{23}$ This program

${ }^{21}$ GAO, Unauthorized or Bogus Entities Have Exploited Employers and Individuals Seeking Affordable Coverage, GAO-04-512T (2004).

${ }^{22}$ See Mila Kofman, et al., Association Health Plans: What's All the Fuss About? 25(6) Health Affairs 1591, 1598 (2006). See also, Mila Kofman, Kevin Lucia \& Eliza Bangit, Proliferation of Phony Health Insurance: States and the Federal Government Respond (Washington: BNA, 2003).

${ }^{23}$ Rosemary Stevens, In Sickness and In Wealth: American Hospitals in the Twentieth 
became the model for the Blue Cross prepaid hospital service plans, which spread rapidly through the 1930s. The Blue Cross plans, in turn, were imitated by the Blue Shield physician services plans, which appeared in the late 1930s. Their success of the Blue plans stimulated competition from commercial insurance companies, which began to sell first hospital, then surgical, and ultimately medical indemnity insurance in the late 1930s and 1940s. ${ }^{24}$ While health insurance was sold predominantly to employment-related groups, nongroup individual policies were also available. By the 1960s and 1970s, most Americans had health insurance, particularly after the Medicare and Medicaid programs were established in 1965 to cover the elderly and the poor.

By the time health insurance came into common use, authority in the states to regulate insurance was well established. State regulation of insurance dates back to the $18^{\text {th }}$ century, and state jurisdiction over insurance regulation was confirmed by the Supreme Court's decision in Paul v. Virginia, which held that insurance was not sold in interstate commerce, and thus not subject to federal control. ${ }^{25}$ In 1944, the Supreme Court reversed itself, holding that insurers were engaged in interstate commerce and thus governed by the federal antitrust laws. ${ }^{26}$ Congress quickly adopted the McCarran-Ferguson Act, ceding jurisdiction over insurance regulation back to the states except where Congress explicitly provided otherwise. ${ }^{27}$ An attempt by the Federal Trade Commission to regulate direct mail marketing by state-regulated health insurers was rebuffed by the Supreme Court in 1958, and while the Court held in 1959 that McCarranFerguson did not block FTC regulation of direct marketing by an insurer outside of the state in which the insurer was located, ${ }^{28}$ the federal government honored the spirit of the McCarranFerguson Act thereafter and did not play an active role in insurance regulation until the 1970s.

State regulation has long been coordinated by the National Association of Insurance Commissioners (NAIC), founded in 1871. The NAIC has an ambiguous status, in part a private trade association and in part a support center for government officials, but also largely dependent on the insurance industry for financial support through fees it collects for database filings and for technical support and advice. ${ }^{29}$ NAIC model statutes and regulations often form a template for

Century, (New York: Basic Books, 1989), 137.

${ }^{24}$ See Timothy S. Jost, Health Care at Risk: A Critique of the Consumer-Driven Movement (Durham: Duke University Press, 2007), 54-62.

${ }^{25}$ Paul v. Virginia, 8 Wall.168 (1869).

${ }^{26}$ In United States v. Southeastern Underwriters Association, 322 U.S. 533 (1944).

${ }^{27} 15$ U.S.C.A. §§ 1011, 1012.

${ }^{28}$ FTC v. National Casualty Co. 357 U.S. 560 (1958); FTC v. Travelers Health Association, 362 U.S. 293, 297 (1960).

${ }^{29}$ See Susan Randall, Insurance Regulation in the Untied States: Regulatory Federalism and the National Association of Insurance Commissioners, 26 Florida State University Law 
the laws and regulations adopted by the separate states, and thus bring a certain uniformity and national character to insurance regulation.

\section{B. Financial Responsibility}

From the beginning, the states regulated commercial health insurance as part of the larger life and accident insurance industry. This regulation focused primarily on the financial responsibility of insurers, long a concern of state insurance regulation. ${ }^{30}$ Insurer solvency remains a serious concern of the states, and lies at the heart of their objections to recent proposed federal legislation that would free health insurers from state regulation, discussed later in this paper. Insurers are required to meet specific capitalization requirements as a condition of initial licensure and to maintain reserves sufficient to meet their ongoing obligations. ${ }^{31}$ Insurers must regularly file audited financial reports with the states and are subject to periodic examinations and audits by state insurance departments. States have proceedings in place to manage insolvent insurers (often through transferring their obligations to ongoing insurance concerns) and have solvency guarantee funds to cover the obligations of insurers that become insolvent.

The application of health insurer financial accountability requirements has long been problematic with respect to some forms of managed care organizations. The federal Bankruptcy Code expressly excludes insurance companies from its coverage, leaving the issue of insurer solvency to the states. ${ }^{32}$ It was for a time arguable that traditional staff-model HMOs were service providers rather than insurers, and subject to oversight by the bankruptcy courts rather than by state insurance regulators, but the Supreme Court's pronouncement in 2002 that HMOs are insurers would seem to settle this issue. ${ }^{33}$ When provider-sponsored organizations and integrated delivery systems became common in the 1990s, they similarly contended that they should not have to meet the same financial responsibility requirements as insurers, because their contractual obligation was to provide services rather than to carry financial risk. ${ }^{34}$ The practice

Review 625 (1999).

${ }^{30}$ O.D. Dickerson, Health Insurance (Homewood, Ill: Richard D. Irwin, 1963), 608-610, 613-14.

${ }^{31}$ See, discussing insurance financial responsibility regulation, John L. Akula, Insolvency Risk in Health Carriers: Innovation, Competition, and Public Protection, 16(1) Health Affairs 9 (1997).

32 Bankruptcy Code $\S 109(b)(2)$.

33 See Rush v. Parham, 536 U.S. 355, 371 (2002). See, further discussing this issue, Craig P. Druehl, HMO and Insurance Insolvency: The Benefits and Detriments of a Federal System, 23 American Journal of Law and Medicine 487 (1997).

34 See Allison Overbay \& Mark Hall, Insurance Regulation of Providers That Bear Risk, 22 American Journal of Law \& Medicine 361 (1996). 
of “downstreaming” risk through capitated payment of providers or professional groups (which in turn may be at risk for payment of other health care products and services) further complicated the issue of financial responsibility of managed care organizations, particularly when many riskbearing physician groups went bankrupt in the late 1990s. ${ }^{35}$ The provisions of the Balanced Budget Act of 1997, which established Medicare payment for provider-sponsored organizations (PSOs), created a special negotiated rule-making procedure for setting solvency requirements for PSOs, and exempted Medicare PSOs from state requirements under some circumstances. ${ }^{36}$ States have responded variously to the problem of risk-bearing providers, imposing financial responsibility requirements on risk-bearing providers, requiring insurers to assume responsibility for the obligations of downstream risk-bearers who default on those obligations, and requiring providers to hold consumers harmless when risk-bearers fail to compensate them for their services.

\section{Other Traditional Regulatory Concerns}

Financial responsibility was not the only concern of traditional insurance regulation. Regulators required insurers in the emerging health insurance industry to incorporate into their policies "standard provisions" that had been formulated to govern the insurance industry long before health insurance became a significant line of business. These provisions dealt with issues like time limits for making claims and proof of loss. ${ }^{37}$ Insurers were also prohibited from engaging in unfair or deceptive advertising and marketing practices. ${ }^{38}$ All states required insurers to file health insurance policies and most required filing of rates, ${ }^{39}$ but state approval was generally not required before policies or rates went into effect. States generally retained the right to disapprove policies that were "unjust, unfair, inequitable or misleading," interfered with health insurance underwriting or rate-setting practices, believing that market control was adequate. The states also imposed premium taxes on commercial insurers, which

${ }^{35}$ See Anish P. Michael, Putting Health Care Providers at a Loss and Consumers at Risk: Why HMOs Should be held Accountable for the Financial Instability of their Delegated Networks, 35 St. Mary’s Law Journal 169 (2003); Douglas J. Witten, Regulation of Downstream and Direct Risk Contracting By Health Care Providers: The Quest for Consumer Protection and a Level Playing Field, 23 American Journal of Law \& Medicine 449 (1997).

${ }^{36}$ Edward B. Hirshfeld, Katherine Nino, \& Helen Jameson, Structuring ProviderSponsored Organizations: The Legal and Regulatory Hurdles, 20 Journal of Legal Medicine 297 (1999).

${ }^{37}$ Frank Joseph Angell, Health Insurance (New York: Ronald Press, 1963), 500, 523-26. These were replaced by the updated "Uniform Provisions" in 1944, id. at 86-98.

${ }^{38}$ Id. At 504-05, 509-10.

${ }^{39}$ Dickerson, supra note 30, at 610, 614.

${ }^{40}$ Id. at 611. 
served as a significant revenue source. ${ }^{41}$ Finally, coordination of coverage where multiple policies might cover the same risk has long been addressed by statute and regulation, as well as by contract. $^{42}$ But in general, as long as insurers remained solvent, paid premium taxes, met filing requirements, and avoided outright fraud, they were quite free to conduct their businesses as they saw fit.

From the beginning, Blue Cross and Blue Shield plans were regulated somewhat differently from commercial plans. The Blue plans argued that they were nonprofit service benefit rather than for-profit insurance plans, and thus should not be required to meet the capitalization and reserve requirements imposed upon commercial insurers or to pay premium taxes. $^{43}$ In fact they functioned for a time much like public insurers, offering open enrollment to all applicants and charging community rated premiums. Recognizing their role, most states adopted special laws authorizing "health services plans," with many of these laws reducing the financial responsibility requirements imposed on the Blue plans and freeing them from premium taxes. $^{44}$ In exchange, however, the Blues were subject to public service requirements. A number of states, for example, required the Blue plans to have substantial public representation on their boards. Blue plans were required to file a description of their benefit structures and a majority required that these be approved by the state. ${ }^{45}$ A number of states required Blue plans to provide free choice of provider. About half of the states required regulatory approval of Blue Cross and Blue Shield reimbursement or fee schedules. ${ }^{46}$ Most importantly, about two-thirds of the states required prior approval of Blue Cross an Blue Shield rates, ${ }^{47}$ while most of the remaining states regulated rates through subsequent disapproval provisions. Some states required community rating. As hospital cost inflation became a serious problem in the late 1950s and 1960s, a few of the more aggressive states used their rate-making power to force Blue Cross and Blue Shield plans to become more assertive in attempting to control hospital prices. ${ }^{48}$ This set the stage for greater regulatory involvement of in insurance rating practices later in the twentieth century.

${ }^{41}$ Id. at $620-21$.

42 See Abraham, supra note 2, at 163-68.

${ }^{43}$ Robert D. Eilers, Regulation of Blue Cross and Blue Shield Plans, Irwin, Homewood Ill., 1963),135-36, 267-79.

${ }^{44}$ Id. at 135-37, 239-41, 267-79.

${ }^{45}$ Id. at $164-5$.

${ }^{46}$ Id. at 197-200, 204-08.

${ }^{47}$ Id. at 228.

${ }^{48}$ Odin Anderson, The Uneasy Equilibrium (New Haven: College and University Press, New Haven, 1968), 167-68, 195-98. 


\section{Coverage Mandates}

Although regulators were long content to allow the market to determine the actual terms of insurance policies, by the middle of the twentieth century, some states began to look more closely at the actual coverage health insurance policies afforded. In 1949 California adopted a Minimum Benefits Law that prohibited the sale of health insurance policies unless the policy's benefits were "sufficient to be of real economic value" to the insured. The law also imposed several more specific regulatory requirements on insurance policies, and was supplemented by even more specific regulations. This legislation was not reproduced outside California, although the NAIC did briefly consider the minimum coverage issue, and some states did interpret their rate approval powers to include the assurance of a reasonable relationship between premiums and benefits. $^{49}$

Beginning in the 1950s, a number of states limited the ability of insurers to cancel, and in some instances, to refuse to renew health insurance policies. Prior to that time, many insurance policies contained clauses allowing the insurer to cancel at any time with five days notice and a pro-rata return of premiums collected, a provision obviously subject to abuse. ${ }^{50}$ Most of these laws simply prohibited cancellation during the term of the policy or required advance notice of nonrenewal, but North Carolina required up to two years notice of refusal to nonrenew (depending on the length of time the policy had been in force), and New York generally prohibited nonrenewal of policies that had been in force for at least two years. ${ }^{51}$ The New York law also permitted insureds who had lost employee coverage to convert from group to individual policies. $^{52}$

In the 1970s and 1980s, state coverage mandates-statutes requiring health insurers to cover specific persons, services, or providers-became much more common. Among the earliest mandates were laws requiring insurers to cover the newborn children of insureds, which were enacted in all but six of the states by 1980, and laws requiring coverage of handicapped dependents; the services of optometrists, psychologists, and chiropractors; and alcoholism

49 Edwin J. Faulkner, Health Insurance (New York: McGraw-Hill, 1960), 488, 499.

${ }^{50}$ Id. at 336-37. By the 1950s, many insurers offered noncancellable and guaranteed renewable policies that could be renewed for up to 10 years or more, though they usually could not be extended beyond age 65. Dickerson, supra note 30, at 335-54. Usually, premiums could not be raised during the term unless they were raised for the entire class of insureds.

${ }^{51}$ Angell, supra note 37, at 512-14; Dickerson, supra note 30, at 622-24;Faulkner, supra note 49 , at $488-90$.

${ }^{52}$ Dickerson, supra note 30, at 622-623. 
treatment, all of which became common in the 1970s and 1980s. ${ }^{53}$ Coverage mandates continued to spread during the 1990s and through the early 2000s. Some have been enacted now in all or virtually all states (mammography screening, minimum maternity stay, chiropractors, adopted children) and some in only a few (acupuncturists, naturopaths, grandchildren, morbid obesity care). Some mandates require insurers to offer applicants specific forms of coverage, others require coverage actually to be provided. Currently, a third of the states impose more than forty coverage mandates, and all but two impose more than twenty. ${ }^{54}$

A number of arguments are offered in support of mandates. ${ }^{55}$ Some are justified as assuring the availability of public goods or preventing negative externalities. Examples would include vaccine coverage mandates, which help reduce the prevalence of communicable diseases, or emergency care coverage mandates, which prevent insurers from shifting to hospitals the cost of emergency care that hospitals are required by law to provide. Some mandates are justified by adverse selection concerns. If insurers are allowed to exclude coverage for high cost but uncommon conditions (or even some common but avoidable conditions such as pregnancy), persons who need coverage for those conditions will be forced to deal with a limited pool of insurers, who will then need to charge more for coverage (and, indeed, potentially significantly more as healthy insureds defect as the cost of coverage rises). Some mandates may make sense in terms of protecting insureds from opportunistic behavior on the part of insurers interpreting vaguely worded contracts (for example, exclusions of “experimental care”). Others acknowledge the "bounded rationality" of insurance purchasers confronted with a choice among complicated and technical insurance contracts, stepping in to protect those consumers against significant risks they might not consider.

Coverage mandates evoke visceral opposition from insurers and their trade associations, business associations, and pro-market advocacy groups. ${ }^{56}$ These groups argue that mandates

53 State coverage mandates are tracked by the BlueCross BlueShield Association. See Susan S. Laudicina, Joan M. Gardner, and Angela M. Crawford, State Legislative Health Care and Insurance Issues, 2006 Survey of Plans, 73-78 (hereafter "Blue Cross/Blue Shield 2006 Survey”, and to a lesser extent by the National Conference of State Legislatures, See, http://www.ncsl.org/programs/health/healthmc.htm. The BlueCross/Blue Shield Survey lists date of enactment for mandates that it tracks.

${ }^{54}$ Blue Cross/Blue Shield 2006 Survey, supra note 53, at 75.

${ }^{55}$ See, exploring the justifications for mandated coverage laws, Korobkin, supra note 5; Monahan, supra note 5, and Frank A. Sloan and Mark A. Hall, Market Failures and the Evolution of State Regulation of Managed Care, 65 Law \& Contemporary Problems 169 (2002).

${ }^{56}$ See, e.g. Council for Affordable Health Insurance, Health Insurance Mandates in the States (2006); National Center for Policy Analysis, The Cost of Mandates (1997); NFIB, NFIB Advocates Free-Market Reforms Allowing Small Business Owners to Decide the Benefits They 
increase the cost of insurance, both directly by raising premiums and indirectly by increasing moral hazard. The increased cost of insurance, they argue, causes more businesses to self insure, because, as is explained further below, the federal Employee Retirement Income Security Act (ERISA) permits self-insured employee benefit plans to escape state mandates. ${ }^{57}$ Insofar as selfinsurance is inefficient, especially for small businesses, this is likely to decrease the value of insurance. The increased cost of insurance causes other employers to simply drop insurance, thus increasing the number of the uninsured. Alternatively, mandates cause employers to decrease the wages of employees to pay for the mandate. Mandate opponents also argue that mandates are not rational responses to real problems, but rather an irrational reaction by legislators to highly publicized anecdotes or the product of lobbying campaigns by highly organized and well-funded provider groups and disease organizations. ${ }^{58}$ Mandates can also lock in place coverage of medical technologies that are later proven ineffective, like high-dose chemotherapy coupled with autologous bone marrow transplantation for breast cancer. Finally, many mandate critics base their opposition on normative grounds-government should not compel individuals or firms to enter into contracts that they themselves do not choose.

Several early studies seemed to show that mandates indeed reduce the level of insurance coverage. Those studies had serious methodological problems, and more recent studies are more ambivalent in their results. ${ }^{59}$ Although most studies show that mandates increase the cost of insurance and reduce coverage, not all do. Some studies even show that some mandates reduce

Can and Cannot Afford to Offer (2006).

${ }^{57}$ See Gail Jensen, State Variations in Insurance Laws a Major Driver of Employers' Self-Insurance Decisions, 7(1) Changes in Health Care Financing and Organization (Feb. 2004).

58 See, e.g. David Hyman, Regulating Managed Care: What's Wrong With a Patient Bill of Rights, 73 S. Cal. L. Rev. 221 (2000). A recent qualitative study of managed care mandates concluded that the motivations of legislators were mixed, including responses to widelypublicized anecdotes and provider lobbying, but also to widespread complaints from consumers. Mark A. Hall, Managed Care Patient Protection or Provider Protection? A Qualitative Assessment, 17 American Journal of Medicine 932 (2004).

${ }^{59}$ The literature on mandates is immense, particularly if one includes advocacy groupsponsored studies and working papers not published in peer reviewed literature. Among the most cited authors in this area are Gail Jensen, Michael Morrisey, Christopher Conover, and Jonathan Gruber, see Gail A. Jensen \& Michael A. Morrisey, Employer-Sponsored Health Insurance and Mandated Benefit Laws, 77(4) Milbank Quarterly 425 (1999); Frank A Sloan and Christopher J. Conover, Effects of State Reforms on Health Insurance Coverage of Adults, 39 Inquiry 118 (1998); and Jonathan Gruber, State Mandated Benefits and Employer Provided Health Insurance, 55 Journal of Public Economics 433 (1994). The analysis presented here relies heavily on a recent literature review, Alan C. Monheit \& Jasmine Rizzo, Mandated Health Insurance Benefits: A Critical Review of the Literature (New Jersey Dept. of Human Services and Rutgers Center for State Health Policy, 2007). 
the cost of coverage, presumably because they permit the substitution of less expensive forms of care for more expensive, while other studies show that, while coverage mandates may increase cost, they do not significantly reduce employer offers of insurance coverage. ${ }^{60}$

Although the economic logic of the situation compels the conclusion that mandates will increase premium cost and decrease coverage, there are several reasons why these results may not follow ineluctably. First, there is some evidence that small businesses (which are most affected by mandates since large businesses self-insure and mandates often do not apply to nongroup policies) have a low elasticity of demand. Small businesses either offer insurance or do not, but they are not likely to drop or add insurance in response to small fluctuations in cost. Moreover, most mandated benefits (such as acupuncture) have very minor effects on insurance cost, and those that have major effects on cost, such as mental health coverage mandates, involve services that employers are likely to cover in any event. If insured employers are already offering mandated benefits, mandates do not affect their costs. In fact, large self-insured employers often offer mandated benefits even through they are not affected by the mandates because of ERISA, and attempts by states to allow small businesses to buy mandate-free "barebones" policies have had few takers. Third, it may be that employees in fact value mandated benefits and thus are willing to absorb the cost themselves. Surveys consistently show that employees express themselves willing to forego taxable wages in exchange for health insurance coverage at levels approximating the median cost of health insurance coverage. ${ }^{61}$

In response to the concerns of mandate opponents, a number of states have taken steps to limit mandates. Eighteen states have adopted laws requiring that new proposed mandates be subjected to cost-benefit analysis, while an additional eight states also review mandates retroactively to study their effects. ${ }^{62}$ A number of states have adopted laws that excuse very small businesses from coverage mandates, allowing them to purchase bare-bones policies. ${ }^{63}$ It is not clear how effective these laws have been, but in any event it appears that the lobbying of mandate opponents is succeeding-very few new mandates have been adopted since 2001, while some mandates have been repealed.

${ }^{60}$ See James H. Henderson, J Allen Steward, and Beck A Taylor, State-Level Health Insurance and Premium Costs, unpublished manuscript 2005, and Monheit \& Rizzo, supra note 59, at 12-18.

${ }^{61}$ The most recent Employee Benefit Research Institute survey found that over threequarters of workers surveyed preferred employment-based health benefits to \$7,500 in additional taxable income, and of those who preferred health insurance, the median responder would require at least $\$ 12,000$ of additional taxable income to surrender health insurance. 2007 Health Confidence Survey, 28(11) EBRI Notes 2 (Nov. 2007).

${ }^{62}$ See Nicole M. Bellows, Helen Ann Halpin \& Sara B. McMenamin, State-Mandated Benefit Review Laws, 41 Health Services Research 1104, 1108 (2006).

${ }^{63}$ See Amy Snow Landa, More States are Allowing Bare-Bones Health Coverage, American Medical News, Feb. 20, 2006. 
States invariably differentiate in health insurance regulation between large groups (usually over fifty members), small groups (three to fifty members) and, the nongroup market (covering individuals and individual families). ${ }^{64}$ It has long been understood that the large group health insurance market functions rather well, but that the small group and nongroup (individual) markets do not. Virtually all large employers offer health insurance to their full time employees, and some even to their part time employees. ${ }^{65}$ Small employers are much less likely to offer health insurance to their employees, and the nongroup market has remained marginal, covering only a fraction of the uninsured who are not members of groups.

From the perspective of insurers, the small group market is problematic and the nongroup market even more so. ${ }^{66}$ Small groups vary significantly in their risk profile and present a substantial threat of adverse selection, while these problems are even greater within the individual market. Insurers have traditionally responded by underwriting small groups and individually cautiously-denying, cancelling, or refusing to renew coverage for particularly high risk groups and individuals; charging high premiums to other groups and individuals that seem to pose heightened risk (and low premiums to healthy groups and individuals); increasing rates sharply from year to year as the risk profile of an initially healthy group deteriorates; charging a risk premium to give them ample cushion when faces with significant underwriting uncertainty; and using preexisting condition clauses, waiting periods, or post claim underwriting (i.e. revisiting the insurance application after a claim is filed to seek a means of cancelling the policy) to protect themselves against adverse selection. The administrative costs of carrying out these strategies increase the cost of small group and individual policies, which are already much higher than those of large groups because of additional marketing costs and agent commissions.

In many states, the problems of the small group and individual markets were traditionally addressed in part by the Blue Cross and Blue Shield plans, which were insurers of last resort. ${ }^{67}$ As noted above, the Blue plans were for a time more likely to have open enrollment and

${ }^{64}$ See Mark A. Hall, The Geography of Health Insurance Regulation, 19(2) Health Affairs 173 (2000).

65 See Kaiser Family Foundation/Health Research and Educational Trust, Employer Health Benefits, 2007 Annual Survey.

${ }^{66}$ See Mark A. Hall, Reforming Private Health Insurance (AEI Press, Washington D.C., 1994).

${ }^{67}$ See Karen Pollitz, Can Access to Affordable Individual Health Insurance be Sustained? in Alan C. Monheit \& Joel C. Cantor, eds., State Health Insurance Market Reform (Rutledge: New York, 2004) 113, 116. 
community-rated premiums and to be subject to state rate regulation in exchange for tax subsidies. Over time, however, the Blues moved to experience rating and became less willing to take on applicants unacceptable to other insurers. ${ }^{68}$

Starting at around 1990, states began to enact small group market reforms. ${ }^{69}$ The most common of these were guaranteed issue and guaranteed renewal laws, which required insurers that sold policies in the small group market to insure all applicants and to renew policies upon expiration. Another very common reform limited preexisting conditions exclusion clauses. In 1996, as is discussed below, guaranteed issue, guaranteed renewal, and preexisting condition limitation reforms were adopted at the national level by the Health Insurance Portability and Accountability Act. Some of these states have adopted laws requiring insurers to offer a standard policy that must be offered to any small group that desires it. Most states also adopted rating reforms, aimed at limiting the spread of insurance premiums. Rating band requirements typically limit the dispersion of rates between the worst and best risks covered by a particular plan to a specified ratio (e.g. median plus or minus fifteen percent), but because rates can also vary in many states based on other factors, such as age, gender, geographic location, and type of plan, a policy covering a small group of older unhealthy workers in a high cost area could cost sixteen times as much as a policy covering a group of healthy, young workers in a low cost area. $^{70}$ A few states have gone further, requiring community rating (that is, not allowing rates to vary at all based on risk) although most of these states do allow some variance based on factors like age and geographic location. ${ }^{71}$ A number of states also limit the extent to which insurers can raise premiums from year to year.

These reforms have been supplemented in a number of states by attempts to broaden risk pooling to lessen the risk of insurers who accept high risk insureds. A number of states have established risk pools through which small group insurers can voluntarily share their highest risk insureds, and some states make participation in risk pooling mandatory. ${ }^{72}$ A few states have also established state reinsurance programs through which the state assumes the cost of the highest

68 They also lost their federal income tax exemption in 1986, I.R.C. § 501(m),

${ }^{69}$ See, discussing these reforms, Hall, supra note 66; Kosali Ilayperuma Simon, What Have we Learned From Research on Small Insurance Reforms?, in Monheit \& Cantor, supra note 67, at 21; Susan M. Gates, Kanika Kapur \& Pinar Karaca-Mandic, State Health Insurance Mandates, Consumer-Directed Health Plans and Health Savings Accounts (Kauffman-Rand Institute for Entrepreneurship Public Policy, 2007).

${ }^{70}$ Hall, supra note 66, at 38; Mark A. Hall, The Structure and Enforcement of Health Insurance Rating Reform, 37(4) Inquiry 376 (2000/2001).

${ }^{71}$ The Blue Cross/Blue Shield 2006 Survey, supra note 53, at 57, lists thirty-seven states as imposing rating limits in the small group market and twelve as requiring community rating

72 The Blue Cross/Blue Shield 2006 Survey lists nineteen states as having voluntary reinsurance pools and seven as having mandatory reinsurance, Id. 
risk insureds. ${ }^{73}$ Finally, a number of states have established purchasing cooperatives to allow small groups to shop for health insurance with greater bargaining power and lower transaction costs.

Many states have also adopted reforms in the individual market, but these reforms tend to be less widespread and demanding. ${ }^{74}$ The individual market is perceived to be volatile and under threat from adverse selection, and there is concern that aggressive state regulation could destroy the market. As noted above, states have long prohibited the cancellation of individual insurance policies, and virtually all states have now adopted guaranteed renewal provisions in the individual market. ${ }^{75}$ Thirty-one states limit the use of preexisting conditions clauses (which are also limited by federal law where an individual converts from the group to the nongroup market after having been insured for eighteen months or more), and a number of states require guaranteed issue. Only ten states limit the range of rating variation, however, while eight states impose some form of community rating. A handful of states also have voluntary or mandatory reinsurance programs. The primary response of about two-thirds of the states to the problem of providing nongroup coverage to high risk individuals has been to establish state-managed high risk pools to which individuals can turn if they are denied coverage for insurance in the regular market. ${ }^{76}$ The premiums for this coverage are usually quite high-125 to 150 percent of average premiums for comparable insurance-and are thus unaffordable for many high risk uninsureds. Even so, premiums do not cover the cost of coverage, and are supplemented by state funds or

${ }^{73}$ See Katherine Swartz, Reinsuring Health: Why More Middle Class People are Uninsured and What Government Can Do (New York: Russell Sage, 2006).

${ }^{74}$ On individual insurance market reforms see, Beth Fuchs, Expanding the Individual Health Insurance Market: Lessons from the State Reforms of the 1990s (Robert Wood Johnson Synthesis Project, 2004); Symposium, The Individual Health Insurance Market, 25(1) Journal of Health Politics, Policy \& Law (2000); Monheit \& Cantor, supra note 67, in particular, Deborah Chollet, What Have We Learned From Research on Individual Market Reforms?, Monheit \& Cantor, supra note 67, at 46. Mark Pauly and various coauthors have written a number of articles contributing to the understanding of the nongroup market, e.g. Mark V. Pauly and Bradley Herring, Risk Pooling and Regulation: Policy and Reality in Today's Individual Health Insurance Market, 26(3) Health Affairs 770 (2007); Mark V. Pauly, The Nongroup Health Insurance Market: Short on Facts, Long on Opinions and Policy Disputes, Health Affairs Web. Exclusive, 23 October 2002. AHIP periodically publishes as survey of the nongroup market. See AHIP Center for Policy and Research, Individual Health Insurance 2006-2007: A Comprehensive Survey of Premiums, Availability and Benefits (Dec. 2007).

75 The information on individual market insurance reforms that follow come from the Blue Cross/Blue Shield 2006 Survey, supra note 53, at 59. Guaranteed renewal is required by federal law, as is guaranteed issue under some circumstances, see below.

76 See National Association for State Comprehensive Health Insurance Plans, Comprehensive Health Insurance for High-Risk Individuals, 2007-2008 (21 ${ }^{\text {st }}$ ed.). 
assessments against insurers. Only a half dozen state risk pools have 10,000 participants and most states have fewer than 5,000 members.

State insurance rating reforms have not provoked as much opposition from insurers as have other mandates, indeed some have been supported by insurers who were concerned about the volatility of the small group market and welcomed a level playing field. ${ }^{77}$ They have, however, been vigorously opposed by free market advocates and have been received with skepticism by economists. It stands to reason that if insurance premiums are reduced for high risk groups and individuals they must be increased for low risk groups and individuals. Because there are many more low risk than high risk groups and individuals, the trade-off for better access for the high risks could be a substantial increase in low-risk uninsureds. In a worst case scenario, an insurance market could enter a death spiral as more and more low risk insureds left and high risk applicants entered the market, making insurance increasingly unaffordable not just to low risk but also normal risk individuals and groups. ${ }^{78}$ Moreover, as higher risk individuals and groups tend to be older and better compensated than lower risk individuals and groups, there are significant equity issues raised by transferring the costs of health insurance from the former to the latter.

Again, however, reality is more complicated than theory. Early reports claimed that community rating in the individual market had dramatically increased the number of uninsured in states that required it, but later analysis showed that the reports were based on badly flawed research. In fact, empirical studies tend to show that small group reforms have on the whole not had much effect, for good or for ill. ${ }^{79}$ Some higher risk groups have been able to get affordable insurance, some lower risk groups have dropped insurance, but neither effect has been dramatic. Individual market reforms have reduced coverage for low risk individuals in some states, but comprehensive reforms have increased coverage for at least higher income high risk insureds, and again the effect of reforms has not been as dramatic as could have been predicted. ${ }^{80}$ High risk pools in most states have remained small, while purchasing cooperatives have proved unpopular. In fact, insurance coverage at any one time seems to have much more to do with the

${ }^{77}$ Hall, supra note 66, at 32-33.

${ }^{78}$ The death spiral concern may be more theoretical than real, but in both Washington and Kentucky implementation of nongroup market reforms resulted in the exit of virtually all insurers from the market, although the exit may not simply have been the product of adverse selection fears. See Adele M. Kirk, Riding the Bull: Experience with Individual Market Reform in Washington, Kentucky, and Massachusetts, 25 J. Health Politics, Policy \& Law 133 (2000).

79 See Simon, supra note 69; Chollet, supra note 74; Pauly \& Herring, supra note 74; M. Susan Marquis \& Stephen H. Long, Effects of “Second Generation” Small Group Market Reforms, 1993-1997, 38 Inquiry 365 (2001); Len Nichols, State Regulation: What Have We Learned So Far, 25(1) J. Health Politics, Policy \& Law 175 (2000).

80 Fuchs, supra note 74 at $10-14$ 
state of the job market than with the insurance market. Moreover, whatever effects insurance regulation might have had toward increasing prices was overwhelmed by the price-lowering effects of the movement to managed care and of vigorous competition in some insurance markets during the 1990s. In any event, few states have adopted market reforms since the late 1990s.

One effect of state reforms, however, has been the proliferation of attempts to avoid them through the formation of ersatz large groups such as multiple employer welfare exchanges (MEWAs), group trusts, association health plans (AHPs) and other stratagems. ${ }^{81}$ For example, a small business association can offer group insurance as a benefit to its members, resulting in a group that is large enough to escape small group rating requirements. Although many are sponsored by legitimate trade associations, many are what have been referred to as "air breather associations" (open to anyone who breathes air). Although most states regulate in-state associations, about half of the states exempt national associations from some or all of the standards that they apply to in-state insurers. ${ }^{82}$ Association markets have been quite volatile, with group associations actively engaging in cherry picking and charging steep premium increases from year to year, while businesses change associations frequently to obtain lower rates. There is also a long history of scams and fraudulent activity in the association health plan and MEWA markets. ${ }^{83}$

\section{F. Managed Care Reforms}

A third area of state legislative and regulatory activity, particularly during the late 1990s and early 2000s, has been managed care reform. Prepaid group practices, which later came to be know as HMOs, date back to the early days of health insurance. They were for decades subject to vigorous opposition from organized medicine, indeed the American Medical Association was criminally convicted of antitrust violations for its attempts to suppress the Group Health Association of Washington D.C. in $1943 .{ }^{84}$ They were also limited by state free choice of provider laws, adopted by a number of states to permit workers' compensation claimants to go to doctors of their choice rather than to doctors chosen by their employers. ${ }^{85}$ State anti-managed care laws were partially preempted by the federal HMO legislation of 1974, but only for federally-qualified HMOs. ${ }^{86}$

${ }^{81}$ See Hall, supra note 64.

${ }^{82}$ Mila Kofman, et al., supra note 22.

${ }^{83}$ See Mila Kofman, Association Health Plans: Loss of State Oversight Means Regulatory Vacuum and More Fraud (Georgetown Health Policy Institute 2005).

${ }^{84}$ American Medical Association v. U.S., 317 U.S. 519 (1943).

${ }^{85}$ See Elizabeth S. Rolph, et al., State Laws and Regulations Governing Preferred Provider Organizations Santa Monica, Ca.: Rand, 1986, 22.

${ }^{86} 42$ U.S.C. $§ 300$ g et seq. See, tracing the history of managed care regulation, Alice A. Noble \& Troyen A. Brennan, The Stages of Managed Care Regulation: Developing Better Rules, 
As managed care emerged in the late 1980s and early 1990s, one of its primary strategies was to form provider networks. Steering of managed care plan members to provider networks is probably the most important distinguishing characteristic of managed care. The provider network strategy allows managed care organizations to negotiate discounts from providers, to require network providers to comply with other practice limitations, and to steer members to providers with lower cost and/or higher quality practice styles. The nature and degree of restrictiveness of networks became the primary factor for distinguishing among the various types of managed care organizations: HMOs, preferred provider organizations (PPOs), point-ofservice (POS) plans, and provider-sponsored organizations (PSOs).

When managed care began to appear in the late 1980s, free choice of provider laws were joined by any willing provider (AWP) laws. AWP laws require that any provider who is willing to accept the terms offered by a managed care plan can join its network. AWP laws struck at the heart of managed care, and have received a great deal of attention in the academic literature. In fact, however, only about twenty-one states have AWP laws and in fourteen of these states AWP laws apply only to pharmacies or pharmacists. ${ }^{87}$ In only five states do AWP laws seem to apply to providers generally. Further, until the Supreme Court decided in Kentucky Association of Health Plans v. Miller ${ }^{88}$ that AWP laws were not preempted by ERISA, the preemption issue limited their effectiveness. In a few states, however, these laws might have impeded the growth of managed care.

Through the mid-1990s, anti-managed care legislation seemed largely anecdote driven. An 1995 New York Times article about gag clauses (clauses in managed care provider contracts prohibiting providers from discussing non-covered treatment options, disparaging the managed care organization, or discussing confidential payment arrangements) provoked universal adoption of state laws banning gag clauses over the next couple of years. Reports of managed care plan restrictions on maternity stays led to the enactment of "drive through delivery" laws guarantying a forty-eight hour hospital stay for normal deliveries by virtually all of the states and then by the federal government. Managed care plan refusals to pay for emergency room visits deemed unnecessary led to “prudent layperson” requirements, enacted by most states.

By the late 1990s, states became more coordinated and deliberate in their regulation of managed care. ${ }^{89}$ Many adopted comprehensive reform statutes that addressed all aspects of

24 Journal of Health Politics, Policy \& Law 1275 (1999).

${ }^{87}$ See National Conference of State Legislatures, Any Willing Provider, http://www.ncsl.org/statefed/health/AWP.htm.

88538 U.S. 329 (2003).

${ }^{89}$ See, analyzing managed care regulation, Noble \& Brennan, supra note 86; John E. Billi \& Gail B. Agrawal, eds., The Challenge of Regulating Managed Care (Ann Arbor: University of Michigan Press, 2001); Stuart H. Altman, Uwe Reinhardt, \& David Schactman, eds., Regulating 
managed care plans. ${ }^{90}$ Four-fifths of the states adopted external review statues, giving external review entities authority to review managed care plan coverage determinations. Many states adopted laws limiting the use of gatekeeper arrangements and giving plan members direct access to specialists, including gynecologists and obstetricians for women. States also passed laws limiting managed care provider incentive arrangements, although these laws do not outlaw the most common forms of incentive arrangements, such as capitation, bonuses, and withholds, and tended to be largely hortatory in nature. Many states have adopted laws protecting the interests of providers in disputes with managed care organizations, limiting without-cause terminations, giving providers procedural protections in termination proceedings, or requiring managed care organizations to pay providers promptly. Finally, a dozen states have adopted statutes subjecting managed care plans to liability for negligent denials of coverage that cause injuries to their members.

The intensity of legislative activity brought on by managed care has been truly remarkable. Even Congress seriously considered comprehensive managed care legislation, and probably would have enacted legislation including many of the provisions adopted by the states had not the events of September 2001 intervened. The legislative flood ebbed in that year, but by that time managed care had changed significantly from the mid-1990s, becoming far less restrictive. Networks had become larger and looser, utilization review less common and intrusive, provider incentive arrangements less common. Health care costs were also rising rapidly-the cost constraints that managed care brought in the1990s seemed to have faded.

The extent to which a causal connection exists between anti-managed care legislation and the movement toward less restrictive managed care and accompanying cost increases has been the subject of vigorous debate. Those who are opposed to mandates generally tend to see managed care restrictions as just another form of government meddling in otherwise functioning markets, or more specifically as provider-protection legislation enacted in response to selfinterested lobbying. ${ }^{91}$ Most commentators, however, believe that market forces (and bad press) played at least as important a role as the law in loosening up managed care. ${ }^{92}$ Many of the

Managed Care: Theory, Practice, and Future Options (San Francisco: Jossey-Bass, 1999); Symposium, The Managed Care Backlash, 24(5) Journal of Health Politics, Policy \& Law 873 et seq.(1999).

${ }^{90}$ For a table of state managed care laws, see National Conference of State Legislatures, Managed Care State Laws, http://www.ncsl.org/programs/health/hmolaws.htm.

${ }^{91}$ See Hyman, supra note 58; Clark C. Havighurst, The Backlash Against Managed Health Care: Hard Politics Make Bad Policy: 34(2) Indiana Law Rev. 395 (2001).

92 See Mark A. Hall, The Death of Managed Care: A Regulatory Autopsy, 30 Journal of Health Politics, Policy \& Law 427 (2005); M. Gregg Bloche, One Step Ahead of the Law: Market Pressures and the Evolution of Managed Care, in M. Gregg Bloche, ed., The Privatization of Health Care Reform: Legal and Regulatory Perspectives (New York: Oxford, 2003), 22; Peter D. Jacobson, Who Killed Managed Care: A Policy Whodunit, 47 Saint Louis 
perceived abuses addressed by the laws were never widespread or had been abandoned by the time the laws went into effect. A GAO study completed in 1997, for example, failed to find clauses prohibiting doctors from discussing noncovered care options with their patients ("gag clauses”) in any of the 529 managed care contracts it examined. ${ }^{93}$ Many of the prohibitions only affected the practices of industry laggards or outliers. Provisions with wider application, such as external review laws, have been rarely invoked and do not seem to have radically changed managed care practice, although in some states they seem to have been used to expand the rights of plan members. ${ }^{94}$ The reform most vigorously opposed by the managed care industry, liability for negligent denial of services, was adopted in a minority of states and was then held by the Supreme Court to be preempted by ERISA with respect to employee benefit plans. ${ }^{95}$ Like other forms of insurance regulation, therefore, managed care regulation in the end may have in fact not had a dramatic effect, for good or for ill.

\section{G. Deregulation to Facilitate Consumer-Driven Health Care}

Although most state legislative initiatives over the past two decades have tended to increase the regulation of insurance plans, the most recent initiatives have been deregulatory. In 2003, Congress adopted the Medicare Modernization Act, which, among other things, authorized tax subsidies for health savings accounts (HSAs) coupled with high deductible health plans. ${ }^{96}$ The legislation did not preempt state insurance regulation. It did provide, however, that HSA tax incentives would only be available in states that permitted high deductible health plans to be sold. The Treasury Department gave the states until the end of 2005 to repeal any laws limiting health plan deductibles below the levels required by the legislation $(\$ 1,000$ for individuals, $\$ 2,000$ for a family). ${ }^{97}$ Most states rapidly fell into line, repealing legislation inconsistent with the federal requirements. Many states went further, moreover, permitting HMOs to sell high deductible policies as well. Indeed, most states with an income tax enacted laws permitting state tax subsidies for HSAs to supplement the federal subsidies. No state enacted a law limiting consumer-driven health plans.

University Law Journal 365 (2003); Lawrence D. Brown, Anticipated Reactions, Uncommon Denominators: The Political Construction of Managed Care Regulation, in Paul Ginsburg \& Cara Lesser, Understanding Health System Change: Local Markets, National Trends (Chicago: Health Administration Press 2001), 91.

${ }^{93}$ GAO, Managed Care: Explicit Gag Clauses Not Found in HMO Contracts, But Physician Concerns Remain, HEHS-97-175, August 29, 1997

${ }^{94}$ See Gresenz \& Studdert, supra note 19.

95 Aetna Health Inc. v. Davila, 542 U.S. 200 (2004).

${ }^{96}$ I.R.C. § 223.

${ }^{97}$ I.R.S. Notice 2004-43, 2004-27 I.R.B. 10. 
The full regulatory implications of consumer-driven health care may not yet be clear, however. ${ }^{98}$ The federal law allows insurers to manage HSAs. Insurers are not regulated by the federal government when they do so, but are apparently not regulated by the states either. Allowing unregulated financial institutions to hold large sums of money seems like a recipe for disaster. Most high deductible plans are currently offered through managed care organizations. Most of these organizations make their networks available to high deductible plan members and only count against the deductible payments for products and services to the extent they would be covered by the plan. The question will thus arise, do managed care protection statutes protect plan members while they are still spending the deductible? If a high deductible health plan refuses to count a member's expenses against the deductible because it deems the service purchased not medically necessary, can the member use the state's external review procedure? Time will tell. Finally, consumer-driven plans are subject to the same questionable marketing and claims practices as are other health insurance plans, and are likely to cause at least as much consumer confusion. Insurance regulators, may, therefore, find that they have an important role to play in protecting consumers from consumer-driven health care as it becomes more common.

\section{Federal Insurance Regulation}

As noted above, insurance regulation was long the task of the states, not the federal government, a situation reaffirmed by the McCarran-Ferguson Act, ${ }^{99}$ which acknowledged the authority of the federal government to regulate insurance, but stipulated that federal laws that did not expressly purport to regulate the "business of insurance" should not be interpreted to preempt state laws and regulations that do.

The last half century, however, has seen a steady expansion of federal authority over health care finance. To begin, the 1954 Internal Revenue Code established that employer contributions to employment-related health insurance plans were taxable neither to the employer nor the employee. This provision, which confirmed earlier administrative rulings by the I.R.S., was a key factor in the rapid expansion in the mid-twentieth century of employment-related health insurance, which now covers slightly less than sixty percent of Americans. Nondiscrimination provisions of the Internal Revenue Code, which prohibit companies from singling out highly-compensated employees for health coverage superior to that afforded other employees in self-insured plans and section 125 cafeteria plans (which allow employees to exclude from taxation their own share of employment-related health insurance premiums), have gone further to assure that employment-related health benefits are more or less equally available to all full-time employees of a particular employer. ${ }^{100}$ Subsequent laws, extending tax subsidies

98 See Jost, supra note 24, 160-65; Timothy S. Jost \& Mark A. Hall, The Role of State Regulation in Consumer-Driven Health Care, 31 American Journal of Law \& Medicine 395 (2005).

$$
\begin{aligned}
& { }^{99} 15 \text { U.S.C. } \S 20 \\
& { }^{100} 26 \text { U.S.C. } \S \S 105(h), 125(b) .
\end{aligned}
$$


to cover health insurance premiums made by the self-employed and for funds deposited in health savings accounts, have underwritten further extensions of health benefits.

In 1965, Congress established two massive public insurance programs, Medicare and Medicaid, which today cover about eighty million Americans and thirty-three percent of American health care costs. The Medicare program is funded exclusively through the federal government and is administered by the federal government through regional contractors. State law that conflicts with Medicare program requirements-including state regulation of managed care organizations that participate in the Medicare program-is in general preempted by the federal law. ${ }^{101}$ For example, there have been numerous complaints of Medicare Advantage plans being marketed in "chronic and blatant" disregard of state consumer protection regulations, but state regulators have been powerless to act in response to these abuses because of federal preemption. ${ }^{102}$ The relationship between federal and state authority in the Medicaid program is far more complex, as the Medicaid program is funded by both the federal and state governments and administered by the states subject to the federal law governing the program. Medicaid services are currently provided for most Medicaid beneficiaries through private managed care organizations, which in general are licensed by the states and must meet state solvency requirements, but also must meet extensive federal regulatory requirements. ${ }^{103}$ Federal standards governing Medicaid managed care organizations explicitly do not preempt more stringent state regulatory requirements. ${ }^{104}$

The most important intervention of the federal government into insurance regulation, however, has undoubtedly been the Employee Retirement Income Security Act of 1974, ERISA, which has already been mentioned several times. ERISA was adopted primarily to reform pension law, but it also regulates employee benefits. Section 514(a) of ERISA provides that ERISA “shall supersede any and all State laws" that "relate to any employee benefit plan."105 The purpose of this provision seems to have been to permit employers to offer benefit plans on a

${ }^{101} 42$ U.S.C. $\S 1395 w-26(b)(3)$. This preemption gets complicated at the margins. The Medicare statute, for example, explicitly allows state licensing and regulation of managed care plan solvency, while several cases have held that state law may address issues not addressed by federal law, such as tort liability of managed care plans for the acts of their agents. Hofler v. Aetna Healthcare of Calif., 296 F.3d 764 (9th Cir 2002).

102 Robert A. Berenson \& Melissa A. Goldstein, Will Medicare Wither on the Vine? How Congress Has Advantaged Medicare Advantage--And What's a Level Playing Field Anyway?, 1 St. Louis U. J. Health L. \& Pol'y 5 (2007).

10342 U.S.C. $\S \S 1396 b(m)(1)(C), 1396 u-2$.

10442 U.S.C. $\S 1396 u-2(c)(1)(B)$.

10542 U.S.C. § 1144(a). ERISA does not govern government or church-sponsored plans. 
national basis without having to adapt their plans to each state in which they operated. Section 514(a) preemption, however, is subject to a number of exceptions, one of which almost swallows the rule. Section 514(b)(2)(A) saves from preemption state laws that regulate insurers. States are thus free to impose a wide range of regulatory requirements on health insurers that insure employment-related benefit plans, including benefit mandates, "any-willing-provider" requirements, and external review provisions. ${ }^{106}$

The "savings clause," however, is also subject to an exception. Section 514(b)(2)(b) provides that states are not permitted to "deem" employee benefit plans themselves to be insurers. The courts have interpreted this provision to mean that states cannot require employers to offer any particular benefits and cannot impose any regulatory requirements at all on selfinsured plans. ${ }^{107}$ "Self-insurance" is defined to include almost any situation in which the employer bears some risk, even if the employer has a generous reinsurance plan. This creates two dilemmas for states: first, they cannot extend insurance coverage to those currently not covered through employer mandates ${ }^{108}$ and second, if they are too aggressive in requiring health insurers to offer expansive coverage, many employers will simply self-insure, thus escaping state regulation altogether.

Section 514 does not, moreover, fully define the scope of ERISA preemption The Supreme Court has read the remedial provisions of ERISA, $\S 502$, to have their own independent preemptive authority. Indeed, the Court has interpreted $\S 502$ to effect two kinds of preemptionjurisdictional and remedial. First, the Court reads $\S 502$ to allow any ERISA plan administrator sued in state court to remove the case into federal court. Second, the Court interprets $\S 502$ to provide that the only remedy available against an ERISA plan for a denial of benefits or for an interpretation of an ERISA plan is a suit under ERISA. The remedies available under ERISA are very limited-effectively the recovery of the cost of an item or service covered under the plan for which payment is improperly denied. Nevertheless, state lawsuits for recovery of health care costs incurred by the negligent denial or limitation of health care services by a managed care plan are not permitted. ${ }^{109}$

The consequences of the interaction of the various ERISA preemption provisions and their exceptions can be quite bizarre. States can enact laws affecting benefit coverage as long as the effect is indirect rather than direct. They can, for example, enforce hospital rate regulations

106 See, e.g. Kentucky Association of Health Plans v. Miller, 538 U.S. 329 (2003); Rush Prudential HMO, Inc. v. Moran, 536 U.S. 355 (2002).

107 FMC Corp. v. Holliday, 498 U.S. 52 (1990).

108 See, e.g. Retail Industry Leaders Ass' v. Fielder, 475 F.3d 180 (4th Cir. 2007) (holding that Maryland is prohibited by ERISA from requiring Wal-Mart to spend eight percent of its payroll on health benefits).

109 Aetna Health Inc. v. Davila, 542 U.S. 200 (2004). 
that require hospitals to charge self-insured health plans more than Blue Cross plans. ${ }^{110}$ They may not, however, require employers to provide health insurance or to spend any particular amount on health coverage. States can impose virtually any mandate they wish on insured employee-benefit plans, but cannot impose any obligations at all on self-insured plans directly. ERISA itself imposes some procedural and disclosure requirements, but virtually no coverage mandates. Persons injured by managed care benefit denials-regardless of how egregiously negligent and contrary to the terms of the benefit plan the denial may have been-are not permitted to sue in state court and can recover only, at most, the value of the benefit denied in federal court.

In the past two decades, the federal government has taken several further steps toward regulating insurance markets. First, the Consolidated Omnibus Budget Reconciliation Act of 1986 (COBRA) permits several categories of “qualified beneficiaries” who lose employmentrelated health insurance benefits through specified "qualifying events" (such as termination of employment or reduction of hours, divorce, or cessation of dependent status) to extend their coverage, in most instances for a period of eighteen to thirty-six months, by paying 102 percent of the premium or cost of the insurance. ${ }^{111}$ Coverage continuation requirements had been adopted by a number of the states before COBRA, but COBRA extended these requirements to the entire country, including ERISA self-insured plans. Because there is heavy adverse selection against COBRA coverage, this turns out to be one of the most costly insurance mandates.

Second, the Health Insurance Portability and Accountability Act (HIPAA) of 1996 limits the ability of insurers to engage in certain risk selection practices. It prohibits employmentrelated group plans from discriminating on the basis of health status in determining eligibility for enrollment or level of premiums for plan members. ${ }^{112}$ It thus effectively requires community rating within groups. HIPAA further imposes three limits on the use of pre-existing conditions clauses in employment-related group insurance policies-it imposes a reasonably narrow definition of pre-existing condition (excluding, for example, genetic predisposition or domestic violence), it limits the look-back period for determining whether a pre-existing condition exists to six months; and in most instances it only permits the preexisting conditions clause to operate for a maximum period of twelve months. ${ }^{113}$ Insurers must reduce this twelve month period by the length of immediately preceding time periods during which the insured had "creditable coverage,” i.e. another form of insurance, which in many instances completely eliminates preexisting conditions clauses for individuals changing jobs. HIPAA further requires insurers operating in the small group market to guarantee issue and renewability, although it does not

110 New York State Conference of Blue Cross \& Blue Shield Plans v. Travelers Ins. Co., 514 U.S. 645, 654-662 (1995).
11129 U.S.C. $\S \S 1161-1168$.
11229 U.S.C. § 1182(a) \& (b), 42 U.S.C. § 300gg-1.
11329 U.S.C. § 1181, 42 U.S.C. § 300gg 
govern the price at which policies must be offered. ${ }^{114}$ HIPAA also requires insurers that operate in the individual market to offer nongroup coverage to persons who lose prior "creditable coverage” under certain circumstances. ${ }^{115}$ This final provision only applies in states that do not make alternative provision for covering uninsured individuals. Most states do offer an alternative, usually a high-risk pool, as discussed above. Finally, HIPAA requires insurers who offer individual coverage to guarantee renewal of that coverage, except under certain circumstances like nonpayment of premiums. ${ }^{116}$

Other federal laws also affect insurance coverage. Congress has adopted three coverage mandates, requiring insurance plans to provide forty-eight hours of hospitalization for a normal delivery and ninety-six hours for a Cesarean section, to pay for breast reconstruction if they cover mastectomies, and, subject to a number of exceptions, to not apply annual and life-time limits to mental health coverage that are less generous than those applied to physical health coverage. ${ }^{117}$ The Age Discrimination in Employment Act requires employers in general to offer the same coverage or coverage of the same value to their employees regardless of age, ${ }^{118}$ while the Pregnancy Discrimination Act requires employee benefit programs to cover pregnancy and childbirth related services. ${ }^{119}$ The Americans with Disabilities Act (ADA) prohibits at least intentional discrimination against the disabled in insurance underwriting, although as a practical matter it permits insurers to take health status into account as long as they do so rationally. ${ }^{120}$ VI. Interim Balance Sheet on Health Insurance Regulation

State regulation has attempted to assure the financial responsibility of health insurers, protect consumers from fraud and deception, expand the persons, providers, and services covered by health insurance, make health insurance more available to high risk insureds, and rein in the excesses of managed care. Federal law has reinforced state efforts to limit risk underwriting, but has otherwise limited the reach of state regulation by allowing employee benefit plans to opt out of state regulation by self-insuring. The primary justifications for many health insurance regulation initiatives over the past three decades have been consumer-protection and risk pool

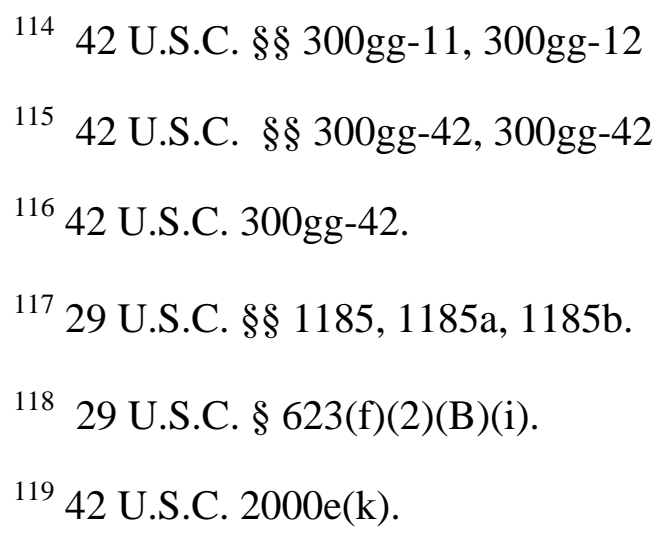

120 An exception to the ADA's prohibition against disability discrimination permits insurance underwriting that is not in violation of state law or a "subterfuge" for violation of the law. 42 U.S.C. § 12201(c). 
expansion. Free market advocates, economists, and some business and insurance interests have at nearly every step, however, challenged insurance regulation as limiting individual choice and increasing the cost of health insurance, which in turn would seem to lead to decreased insurance coverage.

Empirical research suggests that insurance mandates have not in fact dramatically altered insurance markets for good or for ill. Indeed, regulation has often mimicked market trends. The effect of regulation seems to have been primarily at the margins, expanding coverage for some high risk applicants, making it less attractive to some healthy applicants, compelling some marginal insurers to provide better service than they otherwise might have, providing somewhat better coverage for some insureds, keeping or putting some fraudulent insurance arrangements out of business, and discouraging some employers from offering or individuals from purchasing insurance.

Even so, in the end, our experience with insurance and managed care reform would seem to teach us that it is very difficult to make private, for-profit, insurers behave as anything other than private for-profit insurers. The surest route to profit for an insurer is to attract the lowest risk applicants available at any given premium. There is always more money to be made by an insurer by managing risk exposure than by trying to manage health care costs. Beyond this, insurers that intend to remain in the market try to provide as generous benefit packages as the market demands and to maintain a reputation for good service, at least to low-cost insureds. Regulatory efforts may budge insurers slightly from these business strategies, but rarely much or for long. This is particularly true in the current environment, in which any insurer, employer, or individual can simply cease to sell or buy insurance if it does not like the opportunities or options available at any given moment in any given market.

This would suggest that insurance regulation is a thankless, perhaps hopeless, effort. But regulations that bear little hope of success in purely private markets might take on new importance (for good or for ill) in markets in which the purchase of insurance is required, supported by public subsidies, or both. If purchaser exit from a market ceases to be an option, regulation to protect purchasers may become more salient, while the need for regulation may be more pressing if large sums of public money are involved in the purchase of insurance. It is to the role of regulation in a reformed health care system that we next turn.

VII. Insurance Regulation Issues in Health Care Reform

\section{A. What Forms of Regulation Will Health Care Reform Require?}

If the United States is to proceed with health care reform to broaden access to health care, reduce its cost, and improve its quality, as is now being actively debated, health insurance regulation will no doubt need to change. The type of change needed will depend on the approach to reform that is chosen. This section will consider the various options that are widely discussed for reform and the types of insurance regulation each would necessitate. The next section will consider whether insurance regulation reform should take place at the state or federal level. 
In the unlikely event that the United States were to embrace a single payer system, insurance regulation would be greatly simplified. Basic health care services would be covered by public insurance, and private insurance would presumably be limited to covering supplemental non-covered services (as in Canada), to allow those who chose to pay for the privilege to get services more quickly or in more convenient or luxurious settings (as in England), or to cover residual cost-sharing obligations (as in France or under Medigap insurance). This supplementary private insurance would need to be regulated at least to assure insurer solvency and to protect against fraudulent marketing and claims practices, but further mandates or regulatory interventions would probably be unnecessary. ${ }^{121}$

A second possible approach to reform would be to require individuals to purchase coverage under the threat of some form of sanction, such as an excise tax. This is the approach taken by the recent Massachusetts reforms and by recent health care reforms in the Netherlands and in Switzerland. Because such a requirement is imposed on individuals rather than employers, it does not raise issues of ERISA preemption, thus states are free to pursue this course. $^{122}$

If the individual mandate approach to health reform is adopted, several regulatory requirements would seem to be necessary. First, the scope of minimum insurance coverage would need to be established. It makes little sense to require an individual to purchase insurance unless the minimum coverage that must be purchased to comply with the mandate is also defined. If an individual mandate is imposed by a state, required coverage might include all products and services covered by mandates already imposed by the state, although a state with generous mandates might want to consider scaling back. Second, a government implementing an individual mandate would need to make provision for individuals who would not be able to purchase insurance at all or to purchase it at affordable rates because they presented an unfavorable risk profile. Many approaches to this problem are possible, ranging from high risk pools, to reinsurance, to rating band limitations, to community rating. Third, a government implementing an individual mandate might want to establish a purchasing cooperative, like the Massachusetts Connector, to organize the market for individual insurance purchase and reduce transactions costs. Fourth, a government implementing an individual mandate would need to continue traditional oversight over financial responsibility (solvency and reserves) and protections against fraudulent marketing and claims practices. Finally, a government implementing an individual mandate might choose to leave in place managed care consumer

${ }^{121}$ See Timothy Jost, Public and Private Approaches to Insuring the Uninsured, 76 New York University Law Review 419 (2001).

${ }^{122}$ Massachusetts, however, requires employers to make 125 cafeteria plans available to their employees so that the employee can purchase insurance tax free, and the validity of this requirement under ERISA could be challenged, although it is unlikely that a court would invalidate it. See Amy Monahan, Pay or Play Laws, ERISA, and Potential Lessons from Massachusetts, 55 Kansas Law Review 1203, 1220-25 (2007). 
protections to the extent that these address real problems worth addressing. The adoption of comprehensive reform legislation might provide an opportunity for reviewing existing state managed care legislation and determining which provisions have been helpful and which have not.

If health reform is to be accomplished in part through employer mandates, it will have to be implemented through federal legislation. As was established by the litigation involving Maryland's attempt to require Wal-Mart to insure its employees, ERISA prohibits the states from requiring employers to provide employee health benefits. ${ }^{123}$ Were the federal government to require employers to provide their employees with insurance coverage (or to authorize the states to mandate coverage), a definition of minimal coverage would again be necessary. Some means would be necessary to ensure high-risk small employers access to insurance coverage, either through guaranteed issue and renewal and rating band limitations or through reinsurance and risk-pooling, or both. A purchasing cooperative might be helpful for reducing the transaction costs of insurance purchasing for small groups, although if participation were optional the cooperative might disproportionately attract high risk small groups and thus not help much with affordability. Insurer financial responsibility regulation would still be necessary, as would probably be some mechanism for dealing with fraudulent marketing and claims practices. Small groups have in recent years often been the victims of such practices. Finally, states might want to continue in place managed care regulations, as noted above.

Any approach to health care reform that intends to achieve universal coverage through the use of private insurance will require some form of public subsidy for the purchase of private insurance, provided through a tax credit, a voucher, or in some other way. ${ }^{124}$ A significant proportion of Americans do not earn enough income to pay the full price of unsubsidized private insurance. The median income of American households in 2006 was \$48,201. In that same year the median employment-related health insurance family policy cost $\$ 11,480{ }^{125}$ A significant

123 Retail Industry Leaders Ass' v. Fielder, 475 F.3d 180 (4th Cir. 2007); Patricia Butler, ERISA Update: Federal Court of Appeals Agrees ERISA Preempts Maryland's Fair Share Act, http://statecoverage.net/SCINASHP2.pdf (2007). A San Francisco employer mandate was also recently struck down as invalid under ERISA, Golden Gate Restaurant Ass'n v. San Francisco, available at http://lawprofessors.typepad.com/laborprof_blog/files/order_granting_msj.pdf (Dec. 26, 2007), although the district court decision has just been stayed by the Court of Appeals.

124 Tax deductions are not a feasible approach to providing subsidies, as they are completely unrelated to the risk-adjusted price of insurance faced by any one household, are of little or no value to the poorest households who are most in need of subsidization, and are of greatest value to the wealthiest households who have the least need for help.

${ }^{125}$ Kaiser Family Foundation/Health Research and Educational Trust, 2006 Employer Health Benefits Survey. Most of the cost of health insurance premiums would not have been included in household income since it was nominally paid by the employer, so the average American household would have more income available for health insurance were the value of 
proportion of the American population will require public subsidies, therefore, to achieve universal insurance. Under the individual-mandate, private insurance-based, system recently implemented in the Netherlands, sixty percent of the population receive public subsidies to help cover insurance costs. Subsidies will need to be graduated based on household income, probably disappearing at about 300 percent of the poverty level (and thereby covering almost half of the population).

Of course, insurance can be made more affordable by allowing it to cover less. "Barebones," high cost-sharing policies sold in the individual market to young, healthy individuals can be quite inexpensive. But these policies also leave those who purchase them exposed to considerable financial risk, as well as to the possibility of not being able to afford health care when it is needed. A number of studies have been published in recent years examining the plight of "underinsured" Americans. Nearly one in six American families spent more than ten percent or more of their income (five percent or more if low income) on out-of-pocket medical costs in 2001-02. ${ }^{126}$ These families were more than twice as likely not to obtain needed medical care and half again as likely to delay or have difficulty finding needed care as insured Americans generally. ${ }^{127}$ Another study found that adults with health problems with deductibles above $\$ 500$ (and particularly those with incomes below \$35,000 a year) are much more likely than those with lower deductibles not to fill a prescription, not to get needed specialist care, to skip a recommended test or follow-up visit, or to have a medical problem for which they have not sought medical care. ${ }^{128}$ Patients with high deductibles are also much more likely to have problems with medical bills or medical debt. ${ }^{129}$ Nearly half of "underinsured" adults were contacted by a collection agency about medical bills in the year before a recent survey, while more than one-third said that they had to change their lives significantly to pay for medical bills. $^{130}$

Any program to provide public subsidies for private insurance will probably need to ensure that the funds are used to purchase a policy that in fact ensures adequate coverage and

employer-paid premiums passed on to workers and worker's in turn required to pay directly for health insurance. Nevertheless, many American households would be stretched were they required to bear the full cost of health insurance premiums out of pocket.

${ }^{126}$ Mark Merlis, Douglas Gould, and Bisundev Mahato, Rising Out-of-Pocket Spending for Medical Care: A Growing Strain on Family Budgets (Commonwealth Fund, 2006), 3.

${ }^{127}$ Id. at 10.

${ }^{128}$ Karen Davis, Michelle M. Doty, and Alice Ho, How High is Too High? Implications for High-Deductible Health Plans (Commonwealth Fund 2005), 8-10.

${ }^{129}$ Id. at 11.

130 Cathy Schoen, et al., Insured But Not Protected: How Many Adults are Underinsured? Health Aff. Web Excl., 14 June 2005 at W5-296. 
will not expose the insured to financial disaster if health problems eventuate. The SCHIP program, for example, which in many states is used to subsidize the purchase of private insurance, stipulates that the funds must be used to purchase health coverage that complies with certain minimal standards, which can be defined with reference to certain "benchmark" plans, such as Blue Cross/Blue Shield or state or federal employee plans.

An insurance subsidy-based program will also either need some regulation of riskunderwriting and premium rating or full risk adjustment of premium subsidies. Simply giving all eligible persons the same level of income-based subsidy without consideration of age or health status would mean that health insurance would be unaffordable for many older and sicker individuals, and probably unavailable at any price to some of them. At minimum, a sophisticated and generous system of risk-adjustment of premium subsidies coupled with a guaranteed issue and renewal requirement would be needed. If insurers are free to set their premiums at any level they believe justified, regardless of the level of risk-adjusted subsidies, insurance may remain unaffordable in some cases. Some level of limitation on risk bands may thus remain necessary. Reinsurance may also be helpful in assuring that high risk cases can find affordable insurance.

As with other approaches, insurer financial responsibility requirements and consumer fraud protections will continue to be necessary. A purchasing cooperative might not only improve the functioning of the market, but might also facilitate administration and payment of subsidies.

Finally, a system that involves public subsidies should perhaps be accompanied by a regulatory program to limit the products and services covered by subsidized insurance. Most countries that have public insurance systems, as well as the Medicare program in the U.S., have some system for deciding which products and services are covered or not covered by the program. ${ }^{131}$ It is generally agreed that the adoption and dissemination of new health care technologies is one of the most significant causes of the increase of health care costs in the United States. The creation of some means for evaluating the costs and benefits of new health care products and services, with the possibility of making public subsidies available only for insurance plans that do not cover products and services that are clearly not effective, or even cost-effective, might make an important contribution to health care cost control.

\section{B. At What Level of Government Should Reform be Carried Out?}

At the present time, health reform is taking place in the United States at the state level. Although, as noted above, the states have extensive power to regulate insurance in our federal system, their authority is ultimately limited by ERISA, which not only deprives the states of the power to regulate self-insured employee benefit plans, but also limits the extent to which they can regulate insured plans, since an employer can often choose to self-insure if it finds that stateregulated insured plans are too costly or otherwise unacceptable. ERISA also prohibits the states

${ }^{131}$ See Timothy S. Jost, ed., Health Care Coverage Determinations: An International Comparative Study (Berkshire: Open University Press, 2005). 
from imposing health coverage mandates directly on employers and restricts ERISA plan participants and beneficiaries to the very limited judicial remedies available under ERISA when they are denied coverage by an ERISA plan.

One approach to reform, therefore, would be for the federal government to "deregulate" the states by repealing or amending section 514 of ERISA to give the states the authority to regulate all health benefit plans in the state, and possibly even to require employers to offer health insurance coverage. Congress could go a step further and repeal or amend section 502, allowing ERISA plan participants and beneficiaries to sue employment-based insurance plans under state law.

A number of arguments support giving the states more power to reform health insurance. The states are closer to, and thus more responsive to, the needs of their citizens; states are freer to experiment and thus to identify more varied and better solutions to problems than the monolithic federal government; states are better able to address regional variations in health care needs and preferences. ${ }^{132}$ Allowing states to take different approaches also allows persons or businesses with preferences for more or less health care coverage or expenditures a range of options. On the other hand, significant arguments can be made for health care reform at the federal level. The need for health care exists more or less uniformly throughout the country, and it seems unfair for Americans in one state to have excellent health coverage while Americans in another state go without. Allowing health care coverage to vary significantly from state to state also presents the possibility of a form of adverse selection if persons with high-cost health needs move to states with good coverage while businesses that want to minimize health care costs leave for states with low coverage requirements. A "race to the bottom" might occur as states try to attract businesses and shed themselves of unhealthy residents. It might also be harder for provider and disease groups to secure the adoption of inefficient coverage mandates at the national level, where the political process is somewhat more visible and less provincial. ${ }^{133}$ Finally, the repeal of ERISA preemption seems difficult to imagine politically, as it would be opposed by most business interests and insurers in the United States, and even by a number of unions which operate sizeable health benefit plans.

An even less attractive option is that offered by the Health Care Choice Act of 2005 (H.R. 2005), which would allow interstate sales of insurance in any state by any insurer licensed in at least one state. ${ }^{134}$ This proposal would seem to lead inevitably to a race to the bottom, as

${ }^{132}$ See generally, weighing the arguments for and against reform at the federal or state level, Monahan, supra note 5; and Randall R. Bovbjerg, Joshua M. Weiner, and Michael Housman, State and Federal Roles in Health Care: Rationales for Allocating Responsibility, in John Holahan, Alan Weil \& Joshua M. Wiener, eds., Federalism \& Health Policy (Washington: Urban Institute Press, 2003), 25.

133 Only three benefit mandates exist currently at the federal level, while all but two states have more than twenty.

${ }^{134}$ See Elizabeth A. Pendo, The Health Care Choice Act: The Individual Insurance 
states attempted to offer increasingly lenient regulatory environments in exchange for increased access to premium taxes. States would be powerless to guarantee the financial responsibility of insurers located in other states or to police marketing or claims practices fraud by those insurers. State regulators in one state would also be unable to compel the regulatory authorities in the other states to take action against insurance abuses. A long history of fraudulent practices by unregulated insurers counsels against this approach.

If health insurance reform is to take place at the national level, several approaches are possible. One would be national preemption of all state regulation as a means to deregulation. The "deemer" clause, as it were, would be expanded to cover all ERISA plans, or even all insurance plans, eliminating all state mandates and rating and managed care reforms. Though deregulation is very popular in certain quarters, for reasons discussed above, complete deregulation of insurance markets would be likely to lead to even greater disparity in access to care for the rich and the poor, the healthy and the unhealthy, than is currently the case. It would also impose intolerable burdens on providers, particularly safety-net providers, if they were expected to take up the slack in health care provision without compensation. Another alternative would be the establishment of uniform national standards governing state regulation. This approach would lead to greater national uniformity while capitalizing on the regulatory expertise and the greater accountability of state government. One concern with this approach, however, is that it poses potential constitutional problems. The federal government may adopt and enforce its own regulations governing interstate commerce or it may offer financial incentives to the states to take regulatory action (as it does through the Medicaid program), but it cannot constitutionally "commandeer" state officers to enforce federal laws. ${ }^{135}$ There are also practical problems with the delegated regulation approach, moreover, illustrated by the Medicaid program. It leaves the federal government continually exposed to state demands for greater resources and greater flexibility and variation.

Finally, there is the option of federal enforcement of uniform federal standards. This approach would provide all of the benefits of a national approach, while obviously offering none of the benefits of state regulation. It could permit a uniformly regulated national market in health insurance, freeing insurers and employers from having to deal with fifty different state standards and regulators. On the other hand, no regulatory infrastructure exists at the national level for regulating insurance, and the creation of such an infrastructure would be a daunting task.

In the end, it seems to me that the best approach would be to develop uniform national minimal standards for health insurance enforced primarily at the state level. The states would be

Market and the Politics of Choice, 29 W. New Eng. L. Rev. 473 (2007); Mila Kofman \& Karen Pollitz, Health Insurance Regulation by States and the Federal Government: A Review of Current Approaches and Proposals for Change (Georgetown University Health Policy Institute 2006).

${ }^{135}$ Prinz v. United States, 521 U.S. 989 (1997); New York v. United States, 469 U.S. 528 (1985). 
given authority to enforce the national standards against all health plans in the state, including ERISA plans. States would not be required to enforce the national standards, but only in those states that did so would households be eligible for federal tax credits or other subsidies for health insurance for lower income residents, much as is now the situation with respect to access to federal tax subsidies for HSAs. States that accepted the tax credits for their residents could not apply less stringent insurance regulation standards than the federal standards. If three or more states, however, banded together, they could impose standards more protective of their residents, just as the federal air pollution law has allowed states that prefer air pollution standards more restrictive than the federal standards to adopt the California standards. This approach would achieve national uniformity while allowing some room for state flexibility.

\section{Conclusion}

However one judges the effectiveness of health insurance regulation to date, it is difficult to imagine a reformed health care system without health insurance regulation. This regulation could be smarter and leaner than the regulation found today, and may very well take place at a different level of government. But insurance regulation, like the poor, will always be with us. 